\title{
Kadonnutta me-politiikkaa etsimässä
}

T. Seddon, L. Henriksson ja B. Niemeyer (toim.). Learning and work and the politics of working life. Global transformations and collective identities in teaching, nursing and social work. Routledge $2010.231 \mathrm{~s}$.

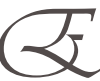

ri puolilla maailmaa asuvat kirjan toimittajat havaitsivat, että heidän yliopistotyössään oli tapahtunut identtisiä muutoksia. Melbournelainen Terri Seddon laski, että hänen pakolliset tehtävänsä veivät 197 prosenttia työajasta - ilman tutkimustyötä. Tamperelainen Lea Henriksson pohti, mitä on lojaalisuus ja kelle olla työssään lojaalinen - tutkimukselle, työnantajalle, verkostoille, vai mille. Beatrix Niemeyer Saksan Flensburgista kertoi työnsä yksinäisyydestä ja pätkätyökurimuksesta.

Opetus, hoito- ja sosiaalityöt ovat muuttuneet tai häiriintyneet tavoilla, jotka vaikuttavat näillä aloilla työskentelevien valta- ja muihin suhteisiin, työn rajoihin, resursseihin ja ammatti-identiteettiin. Hallitusten tietotalouteen, kilpailukykyyn ja elinikäiseen oppimiseen suuntautuva politiikka ravistelee myös ihmistöiden eetosta. Erilaiset konfliktit ja jännitteet näyttävät olevan väistämättömiä ja ei-neuvoteltavia. Globaalien muutosten kuten ei-valinnaisen yksilöllistymiskehityksen ja ammattien fragmentoitumisen hämmentäminä kirjan toimittajat ja muut kirjoittajat kysyvät, mistä löytyy uusia aineksia kollektiivisuuteen, jaettuihin kokemuksiin ja Richard Sennettiin kuvaamaan "me-politiikkaan". Teemat on koostettu selkeästi, ja kirjassa on varsin hyvin onnistuttu välttämään artik- kelikokoelmille ominainen hajanaisuus.

Yhteisyys nähtiin ennen paljolti kasvatuksen tulokseksi silloin, kun koulutusjärjestelmä oli vielä osa kansakunnan rakentamista ja kansalaiseksi kasvamista. Nyt koulutusjärjestelmässä painotetaan kilpailukykyä ja elinikäistä oppimista yksilöiden henkilökohtaisen kilpailukyvyn edistämiseksi.

Työelämää hallinnoidaan paljolti kielellisesti. Opetus- sosiaali- ja hoitoaloille on yritetty istuttaa monenlaisia käsitekummajaisia, muun muassa "sisäistä yrittäjyyttä’. Peter Millerin ja Nikolas Rosen Governing the present -teoksen mukaan johtamisoppi nikkaroitiin USA:ssa 1970-luvulla. Opin mukaan organisaatioissa ei olisi enää työyhteisöjä tai velvollisuuksien ja oikeuksien mukaan suuntautuvia työntekijöitä, vaan oman ja perheensä hyötyä maksimoivia ja rationaalisia valintoja tekeviä yrittäjäyksilöitä.

\section{Työelämän muutos ei ole luonnonvoimaista}

Organisaatioiden hallinnoinnin uuskieli kuvaa tehokkuutta ikään kuin neutraalisti. Poliittisuuden merkitys ei silti ole lainkaan vähentynyt, vaikka työelämän eriarvoisuutta ja yksilöllistymistä luovat kehityskulut luonnollistetaan. Työelämän hämmentävä saan kuvannut kehitystä, jossa toisistaan eristetyt ja ansaan joutumisen kokeneet ihmiset voivat vähitellen löytää yhteisen kielen ja toimintatavan, kun heille tärkeät arvot ovat uhattuina. Frigga Haug on nimittänyt kasvavaa tietoisuutta työn ja elämän historiallisesta muuttumisesta "historialliseksi elämiseksi" (living historically). Historiallisuus tarkoittaa tässä suurin piirtein sitä, ettei kehityskulkuja enää nähdä ikään kuin luonnollisina, väistämättöminä ja itsestään selvinä, millaisiksi vallitseva uusliberalistinen puhetapa muutokset esittää.

Uudenlaisen me-politiikan mahdollisuudet ja ehdot voivat toimittajien mukaan nousta esiin entisten ammatillisten järjestysten fragmentoituessa ja ammatillisten identiteettien ohentuessa sekä kamppailuissa rajoista ja vallasta määritellä ammatillisia rajoja. Työssä ja ammateissa syntyy uudenlaisia eettisiä dilemmoja. Teoksen eri artikkeleissa kuvataan me-politiikan usein vaikeasti tunnistettavaa syntyä muun muassa pätkätöinä toteutettavissa hankkeissa. Kollektiivisen ammatillisen identiteetin määrittelyssä tärkeämmäksi näyttää tulevan se, mihin olemme menossa kuin se, mistä olemme tulossa.

Lea Henriksson kirjoittaa lähihoitajakoulutuksesta (practical nurse) esimerkkitapauksena hyvinvointityömarkkinoiden muutoksesta. Suomalaiset työmarkkinat ovat muita maita selkeämmin sukupuolittuneet pienipalkkaisen hoito- ja hoivatyön jäädessä naisten vastuulle. Näitä 
työmarkkinoita on suosittu niin kauan, kuin se on sopinut yleiseen sosiaalipolitiikan linjaan. Uusliberalistinen hyvinvointipalvelujen alasajo on iskenyt paitsi hoidon ja hoivan tarvitsijoihin myös naisten työmarkkinoihin. Työttömiä paperityöläisiä tai it-insinöörejä on kehotettu ryhtymään lähihoitajiksi vanhustyöhön. Tällaisen yleislääkehätävaran tarjoaminen aktiivisen työnvoimapolitiikan keinoin on ollut omiaan laskemaan vanhustyön arvostusta. Taloudellisen tehokkuuden kurimuksessa merkkejä on löydetty hoitotyöntekijöiden itsearvostuksen rapautumisesta, ja oikeus ammattiylpeyteen alkaa olla jo ylellisyyttä.

Ammatti-identiteettien hapertuessa tarvitaan uudenlaisia (vasta)kertomuksia ja sanastoa. Aikuiskasvatus-lehden toimituskuntaan kuuluva Karin Filander kirjoittaa kirjassa ammattiopettajien viljelemästä ironiasta. Ironia on usein nähty vallan kannalta harmittomana, vain puhujaan itseensä suuntautuvana henkiinjäämiskeinona. Ironia voi kuitenkin tuoda näkyviin vallitsevia puhetapoja kyseenalaistavia näkökulmia. Maalaus- ja pintakäsittelyalan miesvaltainen opettajakunta naurunalaisti yhdessä alansa koulutuksen uudistusinnon ja korosti tarjotun työelämän kehittäjäroolin sijaan vankan ammatillisen osaamisen pohjalta rakentuvaa kunniallisuutta. Keskiluokkaisessa opettajan tehtävässä ironisointi ei kuitenkaan yleensä saa kovin karnevalistisia sävyjä, vaan tulee esiin lähes huomaamattomana. Vain aivan pieni liioittelu saa asian kääntymään päälaelleen.

Anita Devos, Lesley Farrell ja Terri Seddon kertovat työn ja työelämän uudelleensäätelyn tavoista Australiassa. Heidän tapausesimerkkinsä kertovat epäpoliittisina pidettyjen hankkeiden poliittisuudesta. Esimerkiksi mentorointi tähtää paitsi työn kehittämiseen, myös työelämässä tarvittavien minäteknologioiden kehittymiseen. Tämä Foucault'n käsite merkitsee alun perin keskiajan luostarilaitoksessa syntynyttä tapaa säädellä omaa ruumistaan ja sieluaan toivottujen päämäärien mukaiseksi.

\section{Muuttuvia ammatti- identiteettejä, "meitä"}

Saksalainen koulutusjärjestelmä on viimeiset 30 vuotta ollut uudelleenjärjestelyn ja joustavoittamisen alaisena. Beatrix Niemeyer kuvaa, miten perinteinen oppilaitoskeskeinen järjestelmä vakiintuneine työnjakoineen ei ole riittävästi kyennyt vastaamaan koulu-työelämä-siirtymän haasteisiin. Työntekijän yksilöllisiin kompetensseihin ja kilpailukykyyn valmennettaessa opettaminen ei ole tullut tarpeettomaksi vaan opetustyö on tulkittava uudelleen. Moniammatillinen yhteistyö on luonut uusia työnjakoja ja ammatillisia hierarkioita ja samalla purkanut vanhoja. Uusia mahdollisia "meitä" on tullut päivänvaloon, mutta pragmaattisesti toteutetut uudistukset eivät ole jättäneet paljoakaan tilaa kriittiselle ajattelulle ja yhteiselle reflektiolle.

Chris Kubiak kuvaa "puoliammattilaisten" ja "professionaalien" työnjaon muutoksia brittiläisessä terveydenhuollossa, jota uusliberalistiset uudistukset ovat koetelleet hallituspuolueen väristä riippumatta. Aliresursoidun julkisen terveydenhuollon pelastamiseksi rajattuja ammatinkuvia on laajennet- tu moniosaamiseksi ja niin sanottua tukihenkilöstöä on ammattitutkintojärjestelmän puitteissa (NVQ) koulutettu aiemmin vain professionaalien hoitamiin tehtäviin. Näin lääkärien ja koulutettujen sairaanhoitajien on sanottu voivan keskittyä ydintehtäviinsä, mutta kehitys on paikoin johtanut koulutetuimpien ammattilaisten joutumiseen potilastyöstä paperityöhön, kasvavien raportointivelvollisuuksien pariin. Työyhteisöjen hämmennystä ei vähennä se, että palvelujen tarvitsijat on samaan aikaan määritelty aktiivisiksi kuluttajiksi. Hoitotyö on määritelty uudelleen palvelutuotteiden asiakaskohtaiseksi räätälöinniksi. Osa avustavasta henkilöstöstä näkee lisäkoulutuksen mahdollisuutena, koska se lakkauttaisi heidän tähänastisen näkymättömyytensä (invisibilisation) työpaikalla.

Kuulu työn kehityksen saksalaistutkija, emeritaprofessori Frigga Haug päättää teoksen. Hän rakentaa synteesiä kirjan teemoista ja etsii aiemmat utopiansa hukanneille kasvatukselle, koulutukselle ja työlle tämän ajan utopioita. Haugin mukaan työtä ei tarvita enää lisää, vaan työnjako voitaisiin hoitaa seuraavasti. Jokaisella olisi käytössään noin neljä tuntia palkkatyöhön, neljä tuntia perheelle ja vapaaehtoiseen auttamiseen, neljä tuntia itsensä kehittämiseen ja neljä tuntia politiikkaan. Politiikan olisi lähdettävä alhaalta päin. Hän lainaa Karl Marxia: yhteiskunnan kehitykselle välttämätöntä on kaikkien yksilöiden kehittymismahdollisuus.

\section{Jussi Onnismaa}

Väliotsikot toimituksen 